\title{
Ethylene Glycol/Ethanol Anolyte for High Capacity Alkaline Aluminum-Air Battery With Dual-Electrolyte Configuration
}

Tanawat Phusittananan ${ }^{1}$, Wathanyu Kao-ian ${ }^{1}$, Mai Thanh Nguyen ${ }^{2}$, Tetsu Yonezawa ${ }^{2,3}$,
Rojana Pornprasertsuk ${ }^{4,5,6}$, Ahmad Azmin Mohamad and Soorathep Kheawhom $^{1,5 *}$

${ }^{1}$ Department of Chemical Engineering, Faculty of Engineering, Chulalongkorn University, Bangkok, Thailand, ${ }^{2}$ Division of Materials Science and Engineering, Faculty of Engineering, Hokkaido University, Sapporo, Japan, ${ }^{3}$ Institute for the Promotion of Business-Regional Collaboration, Hokkaido University, Sapporo, Japan, ${ }^{4}$ Department of Materials Science, Faculty of Science, Chulalongkorn University, Bangkok, Thailand, ${ }^{5}$ Research Unit of Advanced Materials for Energy Storage, Chulalongkorn University, Bangkok, Thailand, ${ }^{6}$ Center of Excellence on Petrochemical and Materials Technology, Chulalongkorn University, Bangkok, Thailand, ${ }^{7}$ School of Materials and Mineral Resources Engineering, Universiti of Sains Malaysia, Nibong Tebal, Malaysia

Aluminum-air batteries (AABs), due to their low cost and high specific capacity, receive much attention nowadays. Nonetheless, a vital problem curbing wide application of AABs is corrosion of the aluminum (Al) anode, which is triggered by hydrogen evolution reaction (HER). Therefore, this work tackles the problem of anode corrosion in an alkaline Al-air flow battery (AAFB) by implementing a dual-electrolyte system. The battery configuration consists of an Al anode | anolyte | anion exchange membrane | catholyte | air cathode. The anolytes in this work are ethylene glycol/ethanol solutions (0, 5, 10, 20 , and $30 \%)$ v/v containing $3 \mathrm{M}$ potassium hydroxide $(\mathrm{KOH})$. A polymer gel electrolyte (Carbopol ${ }^{\circledR} 940$ ) is employed as the catholyte. The corrosion of an Al electrode in the anolytes is duly examined. It is significant that when the ratio of ethylene glycol exceeds $5 \% \mathrm{v} / \mathrm{v}$, this negatively affects the dissolution process and suppresses Al corrosion. Furthermore, the battery using the anolyte with $5 \% \mathrm{v} / \mathrm{v}$ ethylene glycol, at a discharge current density of $5 \mathrm{~mA} / \mathrm{cm}^{2}$, demonstrates peak power of $3.75 \mathrm{~mW} / \mathrm{cm}^{2}$. The battery also exhibits the highest specific discharge capacity of $2,100 \mathrm{mAh} / \mathrm{g}_{A l}(70 \%$ utilization of Al) at a discharge current density of $2.5 \mathrm{~mA} / \mathrm{cm}^{2}$. In general, the dual-electrolyte system affirms its effectiveness in controlling anodic corrosion, quelling passivation of the Al surface in the alkaline AABs and boosting discharge capacity. $\mathrm{KOH}$ in ethylene glycol/ethanol solution is a promising anolyte being more environmentally friendly, less toxic and providing favorable electrochemical performance.

Keywords: aluminum-air battery, corrosion, dual-electrolyte, flow battery, specific capacity, ethanol, ethylene glycol

\section{INTRODUCTION}

Metal-air batteries (MABs) are among the lightest and highest energy density batteries. Traditionally, MABs use a metal anode and an air cathode consuming oxygen directly from ambient air (Li and Lu, 2017; Liu et al., 2017; Lao-Atiman et al., 2019). Several types of MABs have been developed e.g., lithium-air (Nomura et al., 2017; Yoo et al., 2017), sodium-air (Dilimon et al., 2017), zinc-air (Hosseini et al., 2018b, 2019; Abbasi et al., 2019), magnesium-air (Li et al., 2017; 
Shrestha et al., 2019), and aluminum-air (Hong and Lu, 2017; Mori, 2017). During discharge, oxidation of the metal anode arises, whilst oxygen reduction reaction (ORR) takes place at the air cathode. The air cathode consists of an ORR catalyst layer and gas diffusion layer having a porous membrane that allows oxygen diffusion from ambient air (Li et al., 2019; Poolnapol et al., 2020).

Aluminum-air batteries (AABs) are specifically intriguing for different reasons. They have been developed as range extenders for electric vehicles supplementing integrated rechargeable batteries. Likewise, AABs have been used in military applications where their high capacity and light weight are of huge advantage. It is noted that aluminum ( $\mathrm{Al}$ ) is low in cost, safe and abundant. Moreover, dissolution of an $\mathrm{Al}$ anode involves a three-electron transfer. The $\mathrm{Al}$ anode is exceptionally light, and as the active cathode material is oxygen from ambient air, the whole package can be much lighter than many other battery types. The low atomic weight and trivalent state of the $\mathrm{Al}$ anode offers a high specific capacity $\left(2.98 \mathrm{Ah} / \mathrm{g}_{A l}\right)$ and high energy density (theoretically $8.1 \mathrm{Wh} / \mathrm{g}_{A l}$ ), which are greater than those of current lithium-ion batteries (LIBs) (Mori, 2019).

During discharge, the $\mathrm{Al}$ anode converts into aluminum hydroxide $\left[\mathrm{Al}(\mathrm{OH})_{3}\right]$ and aluminum oxide $\left(\mathrm{Al}_{2} \mathrm{O}_{3}\right)$. It is evident that these oxide/hydroxide species tend to accumulate at both the anode and cathode and retard electrochemical reactions (Mori, 2019). Importantly, conversion of $\mathrm{Al}(\mathrm{OH})_{3}$ and $\mathrm{Al}_{2} \mathrm{O}_{3}$ back to $\mathrm{Al}$ is rather difficult. Thus far, AABs have just been suitable for non-rechargeable batteries. Work is underway to develop mechanically replaceable $\mathrm{Al}$ anodes so that entire battery packs or the $\mathrm{Al}$ anode could be swapped promptly at refilling stations.

The overall reaction of an $\mathrm{Al}$-air system is described as follows: $\mathrm{Al}+3 / 4 \mathrm{O}_{2}+3 / 2 \mathrm{H}_{2} \mathrm{O} \rightarrow \mathrm{Al}(\mathrm{OH})_{3}$ with a theoretical cell voltage of $2.70 \mathrm{~V}$ (Chen et al., 2015). In an alkaline aqueous electrolyte, half-reactions at the anode are shown, as in Eqs. (1 and 2):

$$
\begin{gathered}
\mathrm{Al}+3 \mathrm{OH}^{-} \rightarrow \mathrm{Al}(\mathrm{OH})_{3}+3 e^{-} E^{0}=-2.30 \mathrm{~V} \\
\mathrm{Al}+4 \mathrm{OH}^{-} \rightarrow \mathrm{Al}(\mathrm{OH})_{4}{ }^{-}+3 e^{-} E^{0}=-2.31 \mathrm{~V}
\end{gathered}
$$

During discharge, the cathodic ORR is represented as in Eq. 3:

$$
1 / 2 \mathrm{O}_{2}+\mathrm{H}_{2} \mathrm{O}+2 e^{-} \rightarrow 2 \mathrm{OH}^{-} E^{0}=0.40 \mathrm{~V}
$$

Parasitic water reduction is shown, as in Eq. 4, where both $\mathrm{HER}$ and $\mathrm{Al}$ oxidation, occurring at the $\mathrm{Al}$ surface, take place:

$$
\mathrm{H}_{2} \mathrm{O}+e^{-} \rightarrow \mathrm{OH}^{-}+1 / 2 \mathrm{H}_{2} E^{0}=-0.83 \mathrm{~V}
$$

The shortcoming of AABs rests on their high rate of selfdischarge. This deficiency is on account of the severe corrosion of the $\mathrm{Al}$ anode caused by the parasitic HER. Though AABs can be stored for an extended period in their unused condition, once discharge begins, they start to degrade extremely quickly. In a month of storage, $\mathrm{AABs}$ can lose eighty percent of their capacity. Corrosion of an $\mathrm{Al}$ anode leads to unacceptably low $\mathrm{Al}$ utilization efficiency (Hopkins et al., 2018). Besides, it results in the production and build-up of hydrogen gas in the cell.
Numerous techniques have been developed to mitigate the corrosion of an $\mathrm{Al}$ anode: namely, (1) introducing additives to the electrolyte (Abdel-Gaber et al., 2010; Liu et al., 2016), (2) using gel electrolytes (Mohamad, 2008), (3) using non-aqueous electrolytes (Gelman et al., 2014), (4) using Al alloys (Abedin and Endres, 2004; Rashvand et al., 2013; Wang et al., 2015a), (5) coating the $\mathrm{Al}$ anode with ceramics (Mori, 2014, 2015), and (6) operating at low temperature (Zuo et al., 2019). Nevertheless, these efforts have proved inadequate and have often made the battery system more intricate.

The mechanisms behind $\mathrm{AABs}$ involve $\mathrm{Al}$ dissolution at the anode and ORR at the cathode. In traditional AABs, anodic self-corrosion is the major challenge. The $\mathrm{Al}$ corrosion issue can be effectively handled by restricting $\mathrm{Al}$ dissolution in a non-aqueous electrolyte. However, in such an electrolyte, ORR is kinetically sluggish. Thus, a dual-electrolyte $A A B$ having an anion exchange membrane separating the organic anolyte and aqueous catholyte was developed (Wang et al., 2014). This configuration conferred flexibility in implementing a very distinctive anolyte and catholyte. By implementing an apposite anolyte, the corrosion of the $\mathrm{Al}$ anode can be considerably suppressed, and a high-performance battery can be achieved.

Methanol offers excellent corrosion inhibition in an alkaline solution (Wang et al., 2007, 2009). Earlier, methanol was applied as an anolyte in dual-electrolyte AABs (Wang et al., 2014; Teabnamang et al., 2020). Results showed that very high discharge capacity could be attained. However, methanol is flammable and volatile. Moreover, it is also toxic when inhaled. Other anolytes, therefore, having lower vapor pressure, being less toxic and more eco-friendly are preferred. Corrosion of an $\mathrm{Al}$ (AA5052) anode in ethylene glycol solution containing $4 \mathrm{M}$ sodium hydroxide $(\mathrm{NaOH})$ was studied in $\mathrm{AABs}$ (Wang et al., 2015b). In an alkaline ethylene glycol solution, it was found that dicarboxylic acid additives enhanced electrochemical activity and discharge performance of AA5052 Al alloy. The corrosion of $\mathrm{Al}$ and $\mathrm{Al}$ alloy in ethylene glycol-water solution with different additives was also investigated. Further, a protective effect of sebacic acid was reported (Zaharieva et al., 2009). The corrosion mechanisms of $\mathrm{Al}$ alloys in ethylene glycol solution were studied (Weon and Woo, 2013). It is noted that precipitation and thickening of aluminum hydroxides are major phenomena affecting the corrosion behavior of $\mathrm{Al}$ alloys. In different solutions, the mechanisms of $\mathrm{Al}$ dissolution are different. In an alkaline aqueous solution, $\mathrm{Al}$ dissolution involves repetitive formation and destruction of thin $\mathrm{Al}_{2} \mathrm{O}_{3}$ layers over the $\mathrm{Al}$ surface; dissolution of $\mathrm{Al}$ is controlled via the through-film dissolution process (Koroleva et al., 1999).

Teabnamang et al. (2020) studied $\mathrm{Al}$ corrosion in $3 \mathrm{M} \mathrm{KOH}$ methanol solutions containing different ratios of water. It was reported that in $3 \mathrm{M} \mathrm{KOH}$ anhydrous methanol solution, the resultant oxide film on the Al surface was compact and smooth. By introducing water to the solution, the properties of the oxide film altered. The existence of water in the methanol solutions led to a loose and porous oxide film. The porous structure thus accelerated the transfer of the reactive species between the $\mathrm{Al}$ surface and the electrolyte. 
Another crucial concern of AABs is passivation of the $\mathrm{Al}$ anode arising from the build-up of discharged products on the surface of the $\mathrm{Al}$ anode. The passivation problem can be solved by employing a circulation of electrolytes. By supplying electrolytes regularly to minimize the concentration gradient of the discharge products, anode passivation can be reduced (Hosseini et al., 2018a; Ryu et al., 2018).

This work sets out to resolve the problem of anode corrosion in an alkaline AAFB by implementing a dualelectrolyte system having a configuration of an $\mathrm{Al}$ anode | anolyte | anion exchange membrane | catholyte | air cathode. $3 \mathrm{M} \mathrm{KOH}$ in ethylene glycol/ethanol solutions (0, $5,10,20$, and $30 \%) \mathrm{v} / \mathrm{v}$ are examined as the anolytes. The corrosion behavior and electrochemical characteristics of an $\mathrm{Al}$ electrode in the anolytes are investigated via hydrogen evolution test (gasometric method), potentiodynamic polarization (Tafel polarization) and electrochemical impedance spectroscopy (EIS). Subsequently, performance of the batteries using different anolytes are investigated.

\section{MATERIALS AND METHODS}

\section{Materials}

The cathode current collector was made of nickel (Ni) foam (99.97\%, 100 pore per inch, $1 \mathrm{~mm}$ thick, Qijing Trading Co., Ltd.,
China). Aluminum (Al) plates (99.99\% Qijing Trading Co., Ltd., China) were employed as working electrodes in the corrosion test and anodes in the AAFB. An anion-exchange membrane (AMI7001S, Membrane International Inc., United States) was applied to separate the anolyte and the catholyte. The electrolyte of the half-cell test and the anolyte of the battery was made from ethanol (99.8\%), ethylene glycol (99\%), and potassium hydroxide pellets (KOH, 99\%), purchased from QRëC, New Zealand. The cathode was prepared using polytetrafluoroethylene (PTFE powder, $1 \mu \mathrm{m}$, Sigma-Aldrich, Singapore), carbon black (Vulcan ${ }^{\circledR}$ BP2000 and XC-72, Cabot Corporation, United States), manganese (IV) oxide $\left(\mathrm{MnO}_{2}, 5 \mu \mathrm{m}, 99.99 \%\right.$, Sigma-Aldrich, Singapore), poly(styreneco- butadiene) (Sigma-Aldrich, Singapore) and toluene (99.5\%, Loba Chemie Pvt Ltd., India). Carbopol ${ }^{\circledR} 940$ polymer (CBP940, Lubrizol Corporation, United States) was used to prepare the polymer gel catholyte. All chemicals were used as received, without any additional refinement.

\section{Battery Fabrication}

Figure 1 depicts a schematic illustration of the dual-electrolyte AAFB. The anode electrode was $(30 \mathrm{~mm} \times 50 \mathrm{~mm} \times 0.19 \mathrm{~mm})$ and weighed $0.8 \mathrm{~g}$. The ethylene glycol/ethanol solutions $(0,5,10$, 20 , and $30 \%) \mathrm{v} / \mathrm{v}$ containing $3 \mathrm{M} \mathrm{KOH}$ were used as anolytes. The catholyte is a polymer gel electrolyte prepared by mixing CBP940 1.2 wt.\% in $3 \mathrm{M} \mathrm{KOH}$ aqueous solution. The gel electrolyte significantly reduced electrolyte loss due to evaporation during

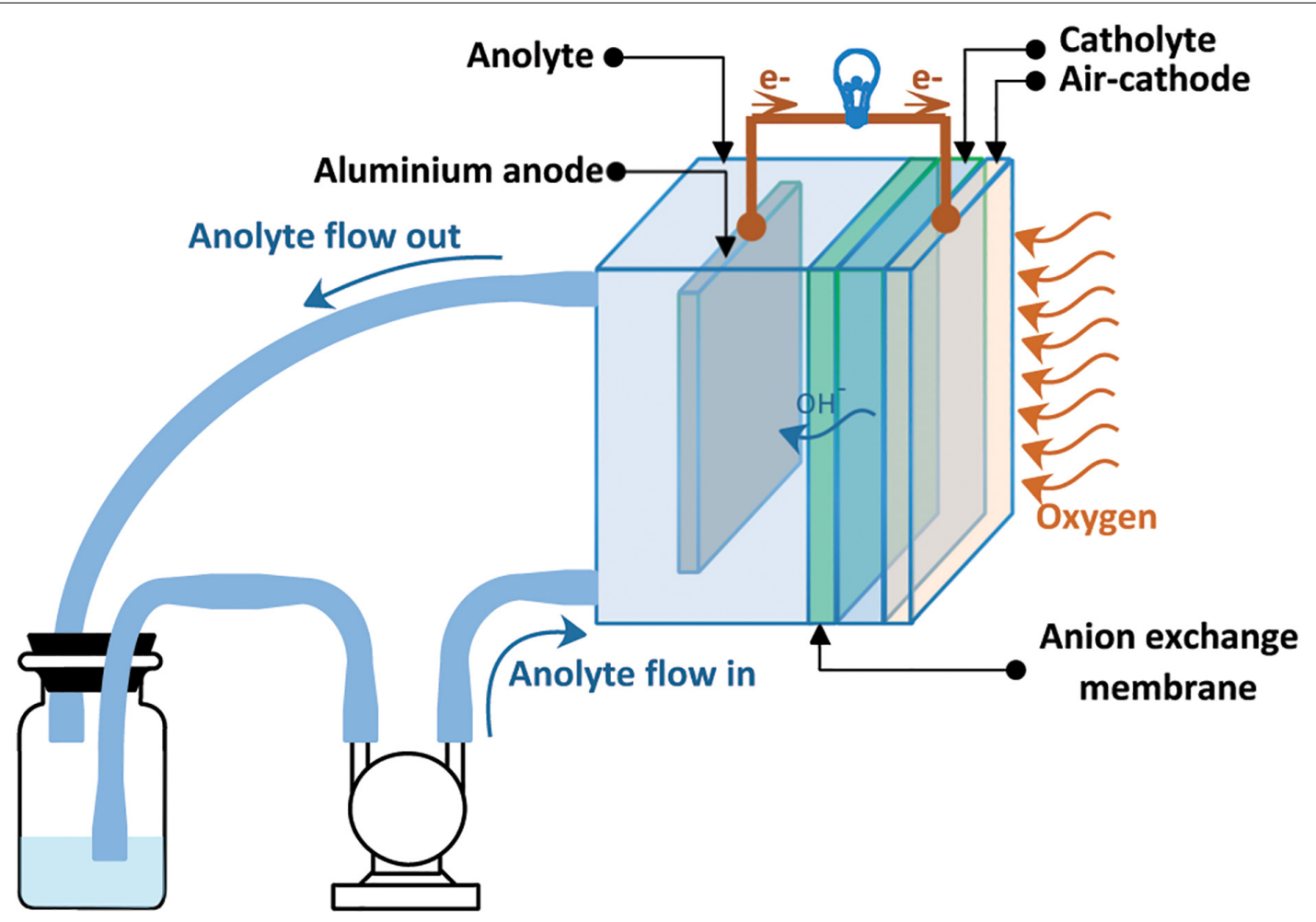

Anolyte reservior Circulating pump

FIGURE 1 | Schematic diagram of the dual-electrolyte Al-air battery with circulating anolyte. 
battery operation. An anion-exchange membrane $(3 \mathrm{~cm} \times 3 \mathrm{~cm})$ was used, as separator, to separate the catholyte and the anolyte. Before the test, the anion-exchange membrane was activated by soaking in an aqueous solution of $5 \mathrm{M}$ sodium chloride $(\mathrm{NaCl})$ at $30^{\circ} \mathrm{C}$ for $24 \mathrm{~h}$.

The air cathode is composed of three layers: the catalyst layer (inner side), the cathode current collector and the gas diffusion layer (outer side). The catalyst layer is in contact with the catholyte. The active area of the cathode reaction is $4 \mathrm{~cm}^{2}$. The cathode was fabricated as a double-sided, coated electrode where the middle layer is the current collector, made of $\mathrm{Ni}$ foam. As for the gas diffusion layer, the outer surface of the air cathode was prepared by coating a mixture of carbon (XC72), D-glucose, and PTFE binder in $10 \mathrm{ml}$ ethanol having a ratio of (40:40:20) wt.\%, respectively. The well-dispersed paste was applied onto the $\mathrm{Ni}$ foam and then pressed using a manual hot press at $350^{\circ} \mathrm{C}$ for $15 \mathrm{~min}$. The gas diffusion layer showed hydrophobicity and helped to prevent leakage of the electrolyte whilst enabling oxygen gas to permeate the cell. To prepare the inner side, both $\mathrm{MnO}_{2} 0.3 \mathrm{~g}$, as the catalyst, and carbon BP2000 $0.7 \mathrm{~g}$ were mixed and dispersed in $8.5 \mathrm{~mL}$ of toluene and stirred for $60 \mathrm{~min}$. Subsequently, $1.5 \mathrm{ml}$ of $7.5 \mathrm{wt} . \%$ poly(styrene-cobutadiene) in toluene solution was introduced. The mixture was stirred for another $60 \mathrm{~min}$. and the prepared paste was coated two times onto the other side of the Ni foam. Finally, the coated $\mathrm{Ni}$ foam was pressed at $150^{\circ} \mathrm{C}$ for $10 \mathrm{~min}$. using a manual hot press.

Figure 2 illustrates the cell design consisting of an aluminum anode, a chamber for the anolyte, an anion exchange membrane (acting as separator), a chamber for the catholyte as well as the air cathode. The distance between the anode and cathode is $18 \mathrm{~mm}$,

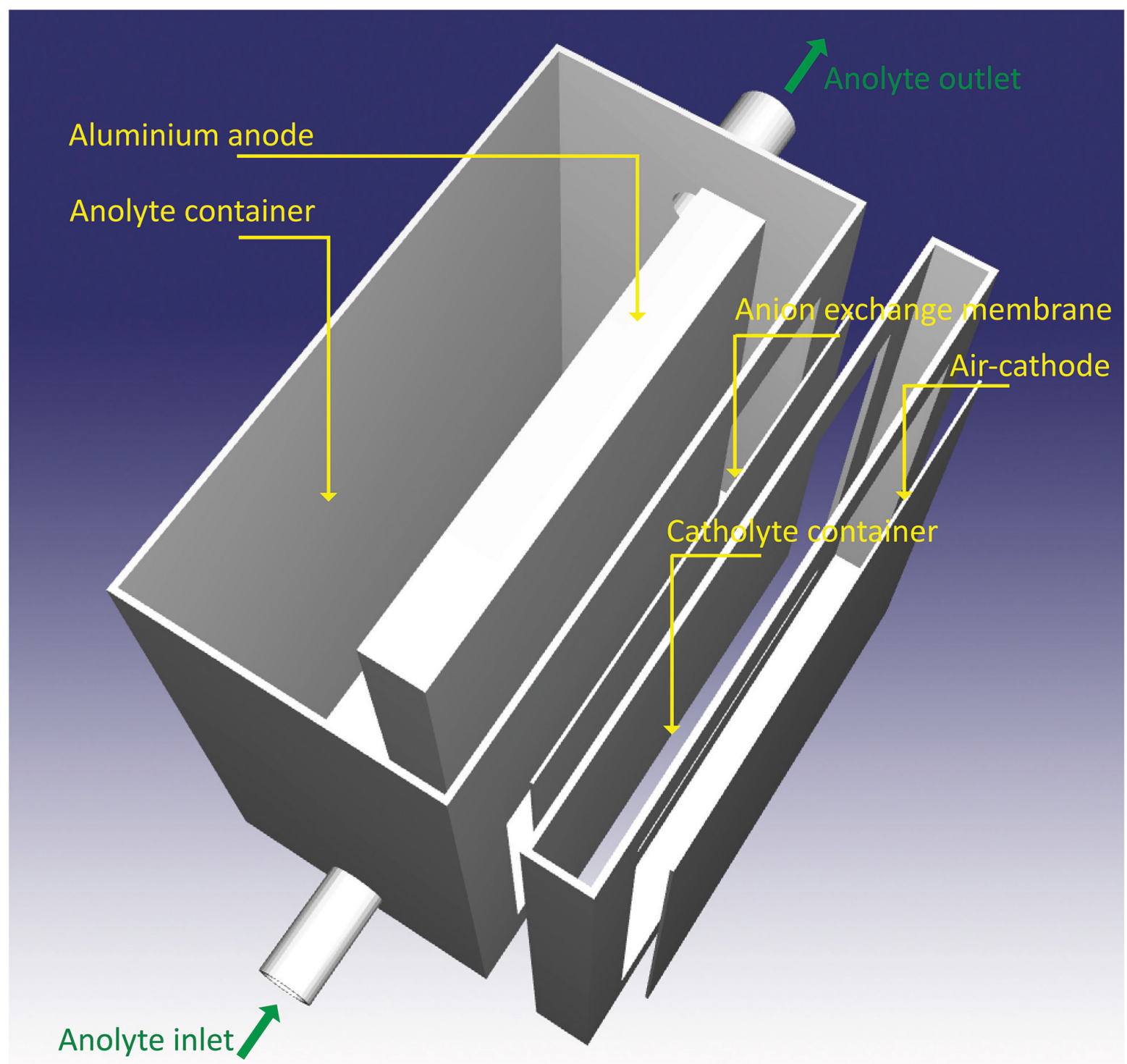

FIGURE 2 | Design of the dual-electrolyte Al-air battery. 
and the distance between the anode to the separator is $14 \mathrm{~mm}$. The distance determines the ohmic resistance of the cell as well as the pressure drop of pump. As the distance increases, the ohmic resistance increases proportionally. However, the pressure drop decreases inversely to the distance.

\section{Corrosion of the Al Anode and Battery Testing}

Figure 3 demonstrates an experimental setup for the hydrogen evolution test (Moghadam et al., 2017). The tests were performed at $30^{\circ} \mathrm{C}$ during $60 \mathrm{~min}$. of immersion in ethylene glycol/ethanol solutions $(0,5,10,20$, and 30\%) v/v containing $3 \mathrm{M} \mathrm{KOH}$. Prior to the test, $\mathrm{Al}$ samples $\left(1 \times 1 \mathrm{~cm}^{2}\right)$ were rinsed with acetone five times repeatedly. Then, each Al sample was immersed into a beaker containing $50 \mathrm{ml}$ of the solution. Then, a funnel was placed over the sample, making sure that all the hydrogen gas generated from corrosion of the sample is accumulated. Next, a burette was installed over the funnel and was initially filled with the solution. The hydrogen which was in the funnel entered the burette and gradually displaced the solution. The burette allowed the volume of generated hydrogen gas to be determined as a function of time. Each test was repeated five times. Reaction rates

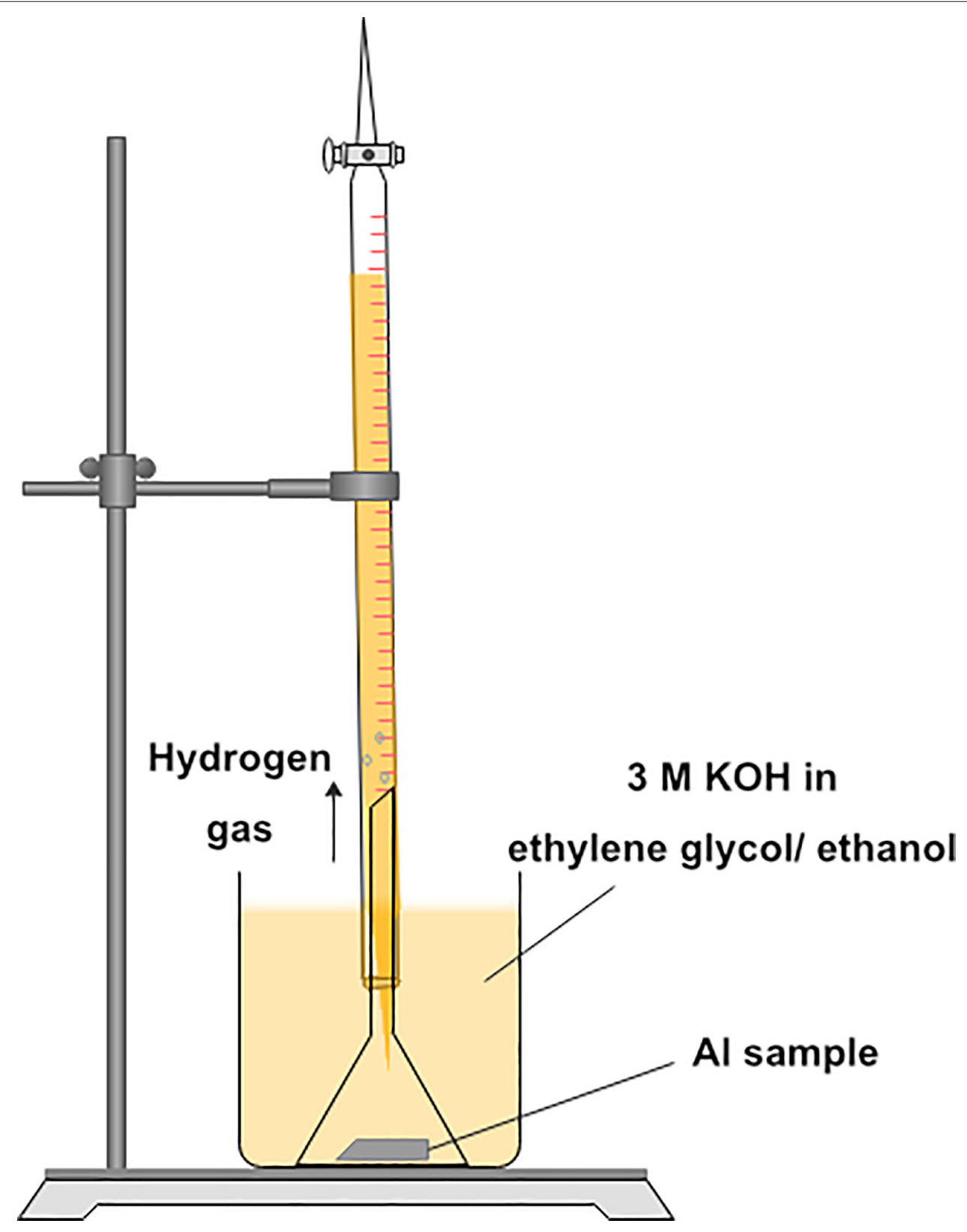

FIGURE 3 | Experimental set up for hydrogen evolution measurement. 

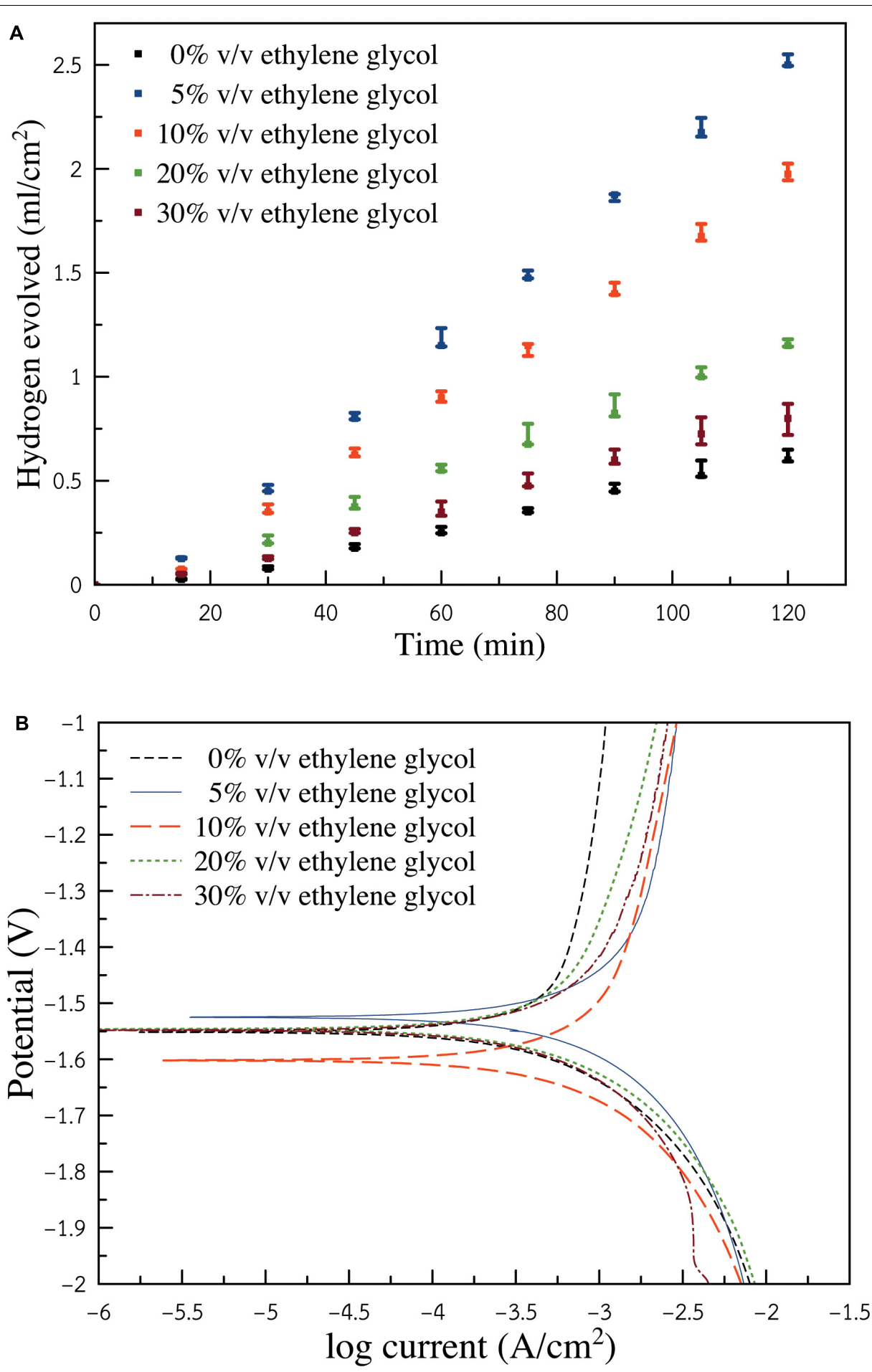

FIGURE 4 | (A) Hydrogen gas evolved from Al sample in ethylene glycol/ethanol solutions (0, 5, 10, 20, and 30\%) v/v containing 3 M KOH (B) Potentiodynamic polarization (Tafel polarization) of Al electrode in ethylene glycol/ethanol solutions (0, 5, 10, 20, and $30 \%) \mathrm{v} / \mathrm{v} \mathrm{containing} 3 \mathrm{M} \mathrm{KOH}$.

were identified by the slope of the straight lines in the gasometry plots.

A three-electrode configuration was employed to study the electrochemical characteristics of the $\mathrm{Al}$ anode in ethylene glycol/ethanol solutions $(0,5,10,20$, and $30 \%) \mathrm{v} / \mathrm{v}$ containing $3 \mathrm{M} \mathrm{KOH}$. The three-electrode cell consisted of: a platinum $(\mathrm{Pt})$ counter electrode $(1 \times 1) \mathrm{cm}^{2}, \mathrm{Ag} / \mathrm{AgCl}$ reference electrode and an $\mathrm{Al}$ plate working electrode $(1 \mathrm{~cm} \times 1 \mathrm{~cm})$. The 
Al working electrode was rinsed three times with acetone prior to the test at $30^{\circ} \mathrm{C}$. A potentiostat/galvanostat (PAR VersaSTAT 3, Ametek Inc., United States) was used to examine electrochemical impedance spectroscopy (EIS) and potentiodynamic polarization. Potentiodynamic polarization was carried out using a scan rate of $5 \mathrm{mV} / \mathrm{s}$ in the potential region cover $(-1.0$ to -2.0$) \mathrm{V}$ vs. Ag/AgCl. Besides, EIS was carried out at a frequency range of $200 \mathrm{kHz}-0.2 \mathrm{~Hz}$ and voltage excitation $5 \mathrm{mV}$ at open circuit voltage (OCV). Further, both battery discharge capacity and voltage-current polarization curve were analyzed by battery testing system (Neware, China). The operation of the battery was carried out at $25^{\circ} \mathrm{C}$.

\section{RESULTS AND DISCUSSION}

Generally, in alkaline aqueous solutions, Al exhibits severe self-corrosion without passivation effect (Pyun and Moon, 2000). Thus, an oxide film, which is a discharge product, is electrochemically formed by the incorporation of hydroxide ions $\left(\mathrm{OH}^{-}\right)$into the film and the migration of $\mathrm{OH}^{-}$through the film toward the $\mathrm{Al} /$ film interface. Corresponding corrosion reactions are shown, as in Eq. 5:

$$
\mathrm{Al}+3 \mathrm{OH}^{-} \rightarrow \mathrm{Al}(\mathrm{OH})_{3}+3 e^{-}
$$

Subsequently, the film is dissolved chemically by the attacking of $\mathrm{OH}^{-}$at the film/electrolyte interface, as shown below in Eq. 6. In addition, the electrons produced by Eq. 5 are consumed instantly by the water reduction reaction, as shown accordingly in Eq. 7:

$$
\begin{gathered}
\mathrm{Al}(\mathrm{OH})_{3}+\mathrm{OH}^{-} \rightarrow \mathrm{Al}(\mathrm{OH})_{4}{ }^{-} \\
3 \mathrm{H}_{2} \mathrm{O}+3 e^{-} \rightarrow 3 \mathrm{OH}^{-}+3 / 2 \mathrm{H}_{2}
\end{gathered}
$$

In Eq. 7, the oxide films, which are produced, are loose and porous. The films cannot protect the underlying Al surface. It is seen that the $\mathrm{Al}$ dissolution herein is controlled by the throughfilm dissolution process (Koroleva et al., 1999).

Self-corrosion of $\mathrm{Al}$ can also take place in the case of anhydrous ethanol or ethylene glycol alkaline solutions. However, the mechanisms of $\mathrm{Al}$ corrosion in alkaline ethanol and ethylene glycol are different from that of alkaline aqueous solutions. Oxide films of Al-ethanol $\left[\mathrm{Al}\left(\mathrm{CH}_{3} \mathrm{CH} 2 \mathrm{O}\right) 3\right]$ and Al-ethylene glycol [Al( $\mathrm{HOCH} 2 \mathrm{CH} 2 \mathrm{O}) 3]$, which show an inhibition effect on the $\mathrm{Al}$ corrosion process, are formed in these solutions. These films can suppress further anodic dissolution of Al (Zhang et al., 2008). For instance, the $\mathrm{Al}$ dissolution was controlled by the precipitation and thickening of the oxide films (Weon and Woo, 2013).

Figure $4 \mathrm{~A}$ presents the relationship between hydrogen gas generated as a function of time. The linear variation for the volume of hydrogen gas progressed according to the time for each condition. The volume of hydrogen can speculate how much $\mathrm{Al}$ consumed itself through HER. It is seen that the electrolyte without ethylene glycol exhibited the lowest hydrogen evolution rate of $0.005 \mathrm{ml} \mathrm{cm}{ }^{-2} \mathrm{~min}^{-1}$. By introducing ethylene glycol to the solution, the hydrogen evolution rate increased. Consequently, the condition of $5 \% \mathrm{v} / \mathrm{v}$ ethylene glycol exhibited the highest hydrogen evolution rate of $0.022 \mathrm{ml} \mathrm{cm}^{-2} \mathrm{~min}^{-1}$. Yet, further increasing the ratio of ethylene glycol resulted in the decrease of HER. The condition of $(10,20$, and 30\%) v/v ethylene glycol showed hydrogen evolution rates of $(0.017,0.010$, and $0.007 \mathrm{ml} \mathrm{cm}^{-2} \mathrm{~min}^{-1}$ ), respectively. However, it is reported that in both ethanol and ethylene glycol, the oxide films produced can retard $\mathrm{Al}$ dissolution kinetics. As for the ethylene glycol/ethanol solution, the surface of $\mathrm{Al}$ was concealed by mixed Al-ethanol and Al-ethylene glycol oxide films. The mixed films provided less protection than the films generated from the alkaline ethanol solution. The presence of ethylene glycol was seen to accelerate HER. The corrosion rate of $\mathrm{Al}$ also increased.

Figure $4 \mathrm{~B}$ depicts the potentiodynamic polarization of an $\mathrm{Al}$ electrode in ethylene glycol/ethanol solutions $(0,5,10,20$, and $30 \%) \mathrm{v} / \mathrm{v}$ containing $3 \mathrm{M} \mathrm{KOH}$. Corrosion potential of the electrolyte containing $0 \% \mathrm{v} / \mathrm{v}$ ethylene glycol was detected at $-1.53 \mathrm{~V}$. As ethylene glycol was introduced, the corrosion potential of the electrolytes showed a negative shift. The negative shift indicated a higher tendency of Al corrosion. Nonetheless, as the ratio of ethylene glycol increased, corrosion potential shifted positively. This indicated that at a higher content of ethylene glycol, Al exhibited lower corrosion tendency, which was in agreement with the result of gasometry of hydrogen evolution. Polarization resistance and other related properties were determined using Butler-Volmer and Stern-Geary equations (Abdel-Gaber et al., 2008; Shinagawa et al., 2015), as shown in Eqs. (8 and 9):

$$
\begin{gathered}
I=I_{\text {corr }}\left(e^{\frac{2.303\left(E-E_{\text {corr }}\right)}{\beta_{a}}}-e^{\frac{2.303\left(E-E_{\text {corr }}\right)}{\beta_{c}}}\right) \\
R_{p}=\frac{\beta_{a}\left|\beta_{c}\right|}{2.303 I_{\text {corr }}\left(\beta_{a}+\left|\beta_{c}\right|\right)}
\end{gathered}
$$

where, $E$ is the electrode potential. $E_{\text {corr }}$ is the corrosion potential. $I$ is the measured current density. $I_{\text {corr }}$ is the corrosion current density. $\beta a$ and $\beta c$ represent the anodic and cathodic Tafel slopes, respectively. By estimating the Tafel slopes as a straight line, polarization resistance $\left(R_{p}\right)$, representing the transition resistance between the electrode and the electrolyte, can be estimated.

Table 1 shows electrochemical polarization parameters viz. corrosion potential $\left(E_{\text {corr }}\right)$, corrosion current density $\left(I_{\text {corr }}\right)$,

\begin{tabular}{|c|c|c|c|c|c|}
\hline $\begin{array}{l}\% \text { ethylene } \\
\text { glycol }\end{array}$ & $\begin{array}{c}E_{\text {corr }}(\mathrm{V} \text { vs. } \\
\mathrm{Ag} / \mathrm{AgCl})\end{array}$ & $\begin{array}{c}I_{\text {corr }}(\mathrm{mA} \\
\left.\mathrm{cm}^{-2}\right)\end{array}$ & $\begin{array}{c}\beta_{a} \\
\left(V \operatorname{dec}^{-1}\right)\end{array}$ & $\begin{array}{c}\beta_{c} \\
\left(V \operatorname{dec}^{-1}\right)\end{array}$ & $R_{p}(\Omega)$ \\
\hline $0 \%$ & -1.53 & 0.57 & 1.52 & -0.27 & 177.24 \\
\hline $5 \%$ & -1.59 & 1.35 & 1.08 & -0.52 & 112.12 \\
\hline $10 \%$ & -1.55 & 1.12 & 1.24 & -0.42 & 121.52 \\
\hline $20 \%$ & 1.55 & 0.84 & 1.25 & -0.34 & 138.65 \\
\hline $30 \%$ & -1.55 & 0.82 & 1.31 & -0.38 & 155.97 \\
\hline
\end{tabular}
anodic slope $\left(\beta_{a}\right)$, cathodic slope $\left(\beta_{c}\right)$, and polarization resistance $\left(R_{p}\right)$. Corrosion rate is proportionally related to

TABLE 1 | Electrochemical polarization parameters of an Al electrode in ethylene glycol/ethanol solutions $(0,5,10,20$, and $30 \%) v / v$ containing $3 \mathrm{M} \mathrm{KOH}$. 
polarization resistance. Higher polarization resistance shows lower corrosion current. Greater polarization resistance indicates greater corrosion inhibition property. It is seen that the lowest polarization resistance was attained when the electrolyte having $5 \% \mathrm{v} / \mathrm{v}$ ethylene glycol was used. Nonetheless, as the ratio of ethylene glycol increased further, polarization resistance gradually increased. The anodic slope shows the corrosion tendency of the anode. The smallest anodic slope $(1.08 \mathrm{~V} / \mathrm{dec})$ and smallest polarization resistance (112.12 $\Omega$ ) was obtained via the electrolyte containing $5 \% \mathrm{v} / \mathrm{v}$ ethylene glycol, indicating the greatest corrosion propensity of the Al electrode. The corrosion current density of the electrolyte containing $5 \% \mathrm{v} / \mathrm{v}$ ethylene glycol was $1.35 \mathrm{~mA} / \mathrm{cm}^{2}$. The greatest anodic Tafel slope $(1.52 \mathrm{~V} / \mathrm{dec})$ occurred in the electrolyte without ethylene glycol. The corrosion current density of the electrolyte without ethylene glycol was found to be $0.57 \mathrm{~mA} / \mathrm{cm}^{2}$ while polarization resistance was $177.24 \Omega$. The Tafel slope suggests how large overpotential is required to increase the reaction rate. The lesser anodic slope suggests higher $\mathrm{Al}$ corrosion tendency. The greater anodic slope and larger polarization show a definitive advantage in the corrosion inhibition of Al. However, it has unfavorable effects on battery performance, as $\mathrm{Al}$ dissolution requires a greater overpotential.

Electrochemical impedance spectroscopy technique was used to examine the characteristics of the Al dissolution process. Figure 5A displays Nyquist plots of $\mathrm{Al}$ electrode in ethylene glycol/ethanol solutions $(0,5,10,20$, and $30 \%) \mathrm{v} / \mathrm{v}$ containing $3 \mathrm{M} \mathrm{KOH}$. All cases exhibited similar characteristics. Similar results were also reported for $\mathrm{Al}$ in alkaline aqueous solutions (Abdel-Gaber et al., 2008). The impedance spectra contain a small capacitive loop at a low frequency, a small inductive loop at a middle frequency, and a large capacitive loop at high frequency. The capacitive semicircle at high frequency is ascribed to the redox reaction of $\mathrm{Al} \leftrightarrow \mathrm{Al}^{+}$which was noted as being the rate-determining step in the dissolution process (Moghadam et al., 2017). The inductive loop at middle frequency arose from an adsorption of intermediates on the Al surface. The other capacitive loop at low frequency is attributed to $\mathrm{Al}^{+} \leftrightarrow \mathrm{Al}^{3+}$ redox reaction (Verma et al., 2015). In an alkaline aqueous solution, $\mathrm{Al}$ dissolution involves the repeated formation and dissolution of thin $\mathrm{Al}_{2} \mathrm{O}_{3}$ films over the $\mathrm{Al}$ surface (Koroleva et al., 1999). Thus, $\mathrm{Al}^{3+}$ ions, formed by the oxidation of $\mathrm{Al}$ at the $\mathrm{Al}_{2} \mathrm{O}_{3}$ film/Al interface, migrated across the films to the electrolyte. Instantaneously, $\mathrm{OH}^{-}$ions migrated across the films to the $\mathrm{Al}$ surface. Therefore, the anodic dissolution of $\mathrm{Al}$ is controlled via the through-film dissolution mechanism.

As for ethanol or ethylene glycol electrolytes, the films of Alethanol and Al-ethylene glycol are involved. These films exhibited a lower migration rate of $\mathrm{Al}^{3+}$ and $\mathrm{OH}^{-}$than that of an alkaline aqueous electrolyte. Consequently, they can suppress the dissolution process of $\mathrm{Al}$ (Zhang et al., 2008).

It is significant that the $3 \mathrm{M} \mathrm{KOH}$ ethanol electrolyte, without ethylene glycol, displayed the highest diameter of capacitive and inductive loops. However, when ethylene glycol was introduced, this led to a decrease in the diameter size of the capacitive semicircle. The presence of ethylene glycol was seen to reduce charge transfer resistance as well as bulk resistance. Hence, the
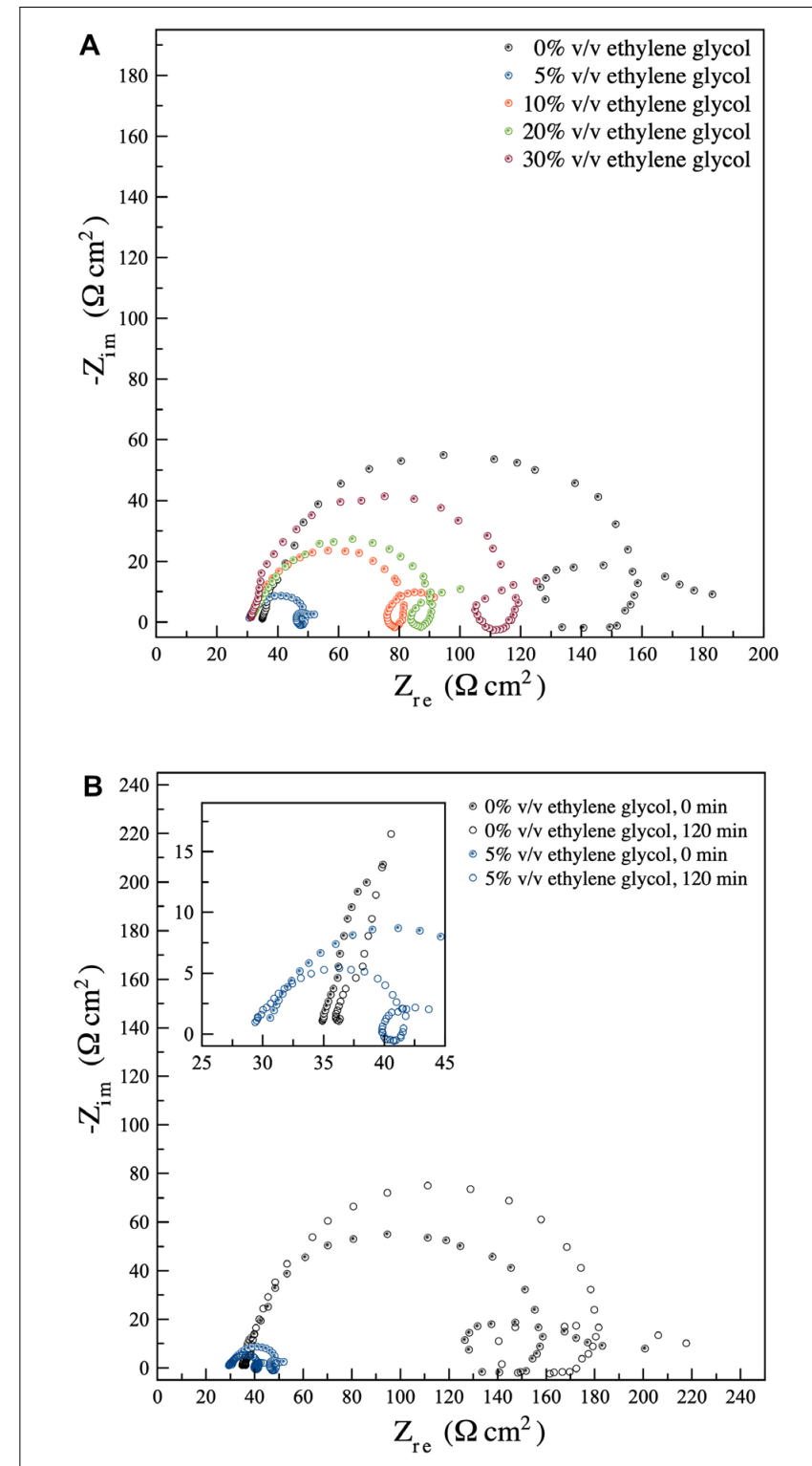

FIGURE 5 | Nyquist plots of EIS, performed at the potential O V (vs. OCV) in the frequency range $200 \mathrm{kHz}$ to $0.2 \mathrm{~Hz}$ with $\mathrm{AC}$ amplitude of $5 \mathrm{mV}$ : (A) An Al electrode in ethylene glycol/ethanol solutions $(0,5,10,20$, and $30 \%) \mathrm{v} / \mathrm{V}$ containing $3 \mathrm{M} \mathrm{KOH}$ (B) An Al electrode in ethylene glycol/ethanol solutions ( 0 and $5 \%$ ) $v / v$ containing $3 \mathrm{M} \mathrm{KOH}$ at different immersion times (0 and $120 \mathrm{~min}$ ).

corrosion rate of $\mathrm{Al}$ increased. Results revealed that the ethanol electrolyte, without ethylene glycol, had the highest charge transfer resistance, indicating that the surface of Al was occupied by the Al-ethanol film, which had the smallest migration rate of $\mathrm{Al}^{3+}$ and $\mathrm{OH}^{-}$. In the case of the electrolyte containing ethylene glycol, the surface of $\mathrm{Al}$ was covered by the heterogeneous films consisting of Al-ethanol and Al-ethylene glycol species. The mixed films showed a higher migration rate of $\mathrm{Al}^{3+}$ and $\mathrm{OH}^{-}$. Consequently, they exhibited faster $\mathrm{Al}$ dissolution kinetics.

The electrolyte containing 5\% v/v ethylene glycol showed the smallest diameter of capacitive and inductive loops, indicating 
the fast kinetics of charge transfer reactions associated with the redox process. However, when the ratio of ethylene glycol was increased, the diameter of capacitive and inductive loops gradually increased. In other words, the charge transfer resistance of the dissolution process became larger as the ratio of ethylene glycol increased. In effect, the dissolution process turned
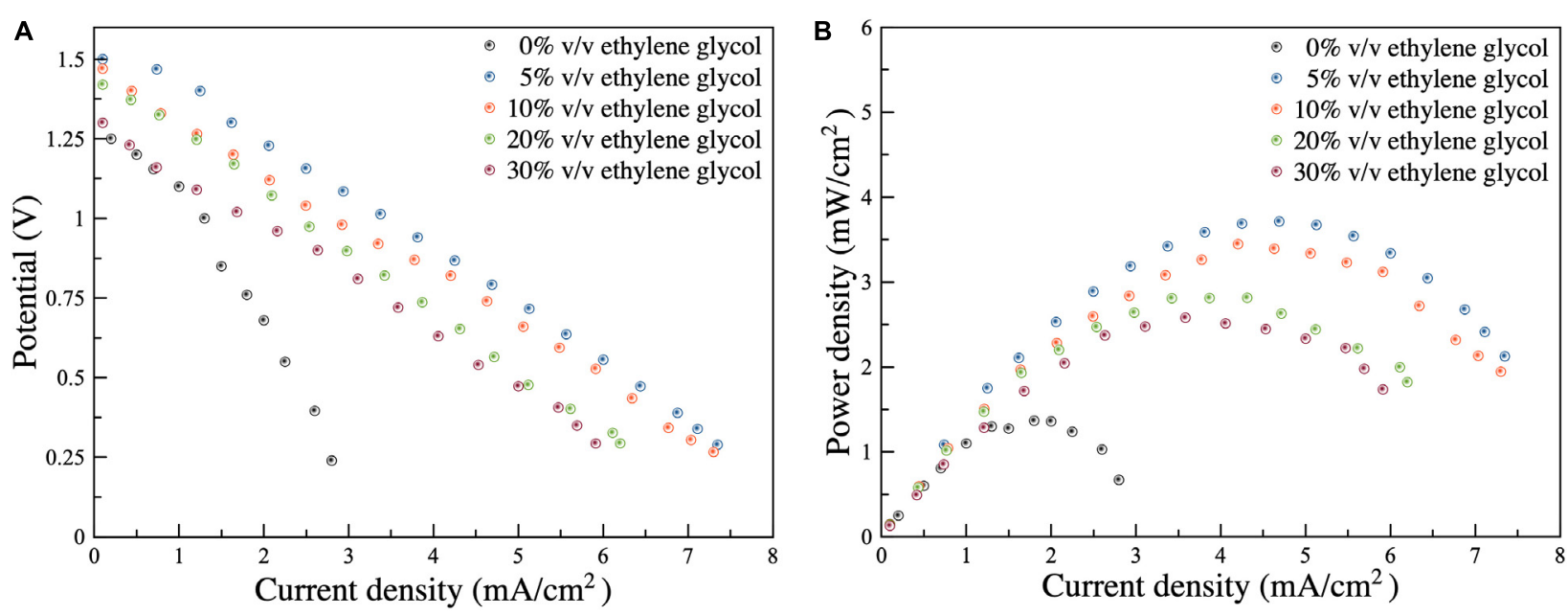

FIGURE 6 | (A) Polarization characteristics of the dual-electrolyte Al-air battery using an anolyte of ethylene glycol/ethanol solutions (0, 5, 10, 20, and 30\%) v/v containing $3 \mathrm{M} \mathrm{KOH}$ (B) Power density as a function of current density for the dual-electrolyte Al-air battery using an anolyte of ethylene glycol/ethanol solutions (0, $5,10,20$, and $30 \%) \mathrm{v} / \mathrm{v}$ containing $3 \mathrm{M} \mathrm{KOH}$.

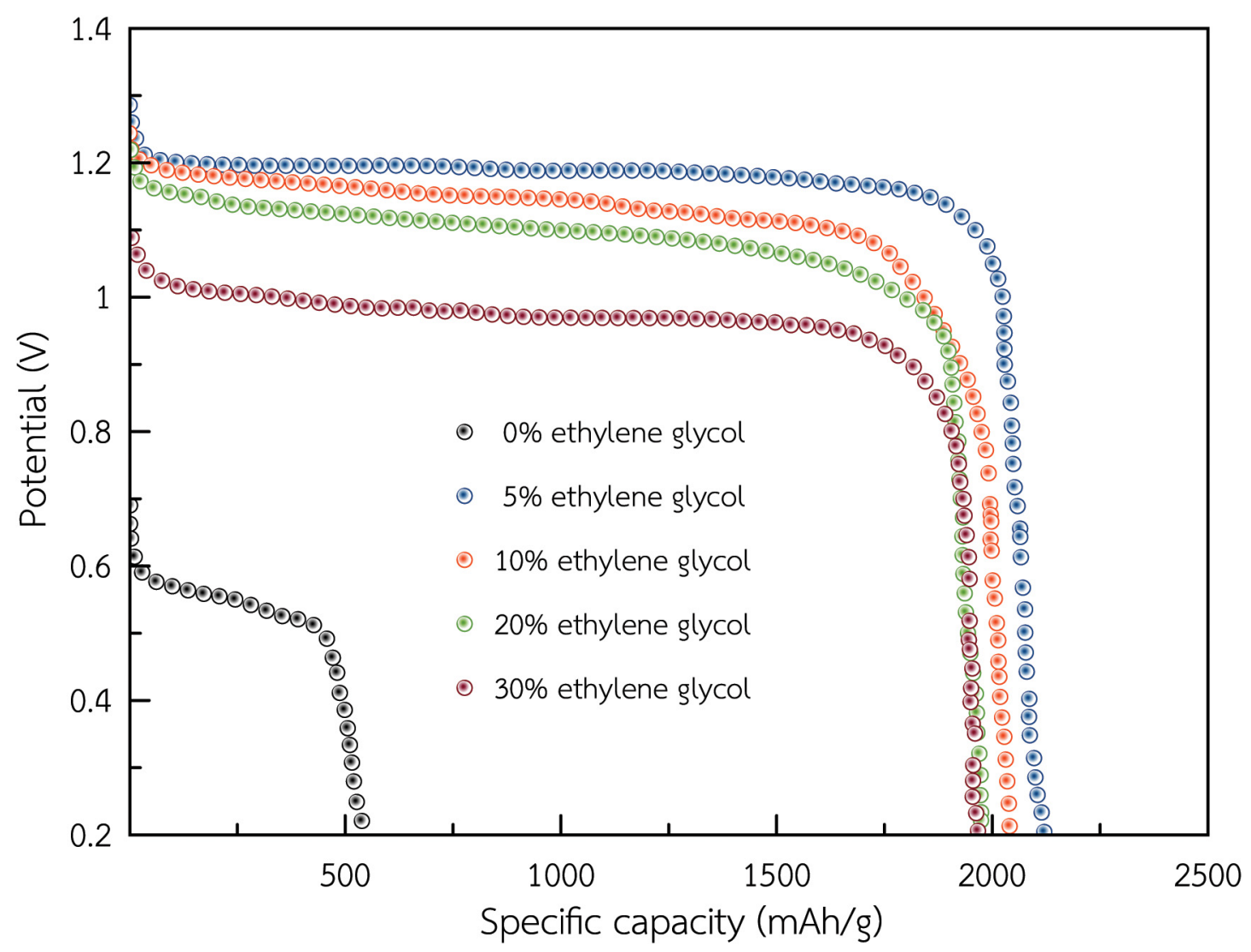

FIGURE 7 | Discharge profiles of the dual-electrolyte Al-air battery using an anolyte of ethylene glycol/ethanol solutions (0, 5, 10, 20, and 30\%) v/v containing $3 \mathrm{M}$ $\mathrm{KOH}$ at a discharge current density of $2.5 \mathrm{~mA} / \mathrm{cm}^{2}$. 
out to be more sluggish; and the system showed enhanced corrosion inhibition.

Figure 5B presents the Nyquist plots of $\mathrm{Al}$ electrode in ethylene glycol/ethanol solutions (0 and 5\%) v/v containing 3 $\mathrm{M} \mathrm{KOH}$ at immediate immersion of $\mathrm{Al}$ and after $120 \mathrm{~min}$. Thus, it was found that the diameters of the capacitive and inductive loops, regarding the $3 \mathrm{M} \mathrm{KOH}$ ethanol electrolyte, without ethylene glycol, increased after $120 \mathrm{~min}$. immersion. At the beginning, the anode was fresh and showed the highest anodic activity (the lowest charge transfer resistance). Then, the charge transfer resistance increased through time. This indicated that the formation of the Al-ethanol films acted as a passivation layer and suppressed $\mathrm{Al}$ dissolution. In comparison, when ethylene glycol was introduced to the electrolyte, the width of the capacitive semicircle decreased with time. That is, the charge transfer resistance decreased, as immersion time increased, signifying that the films produced, consisting of Al-ethanol and Al-ethylene glycol species, exhibited no passivation.

Following the examination of $\mathrm{Al}$ corrosion and dissolution, performance of the dual-electrolyte AAFB was studied. Before the test, the cell was fabricated, and the anolyte was circulated for one hour without the $\mathrm{Al}$ anode. Then, the effects of ethylene glycol/ethanol solution anolytes were studied, at a circulation rate of anolyte $10 \mathrm{ml} / \mathrm{min}$. In Figure 6, the polarization characteristics of the battery are presented. It was observed that the limiting current density increased when ethylene glycol was introduced as follows: $\left(2.80,7.45,7.40,6.30\right.$, and $\left.6.00 \mathrm{~mA} / \mathrm{cm}^{2}\right)$ using $(0$, $5,10,20$, and $30 \%) \mathrm{v} / \mathrm{v}$ ethylene glycol electrolytes, respectively. Maximum power density was calculated via current density and discharge voltage providing: $(1.25,3.75,3.50,2.75$, and $2.50 \mathrm{~mW} / \mathrm{cm}^{2}$ ), respectively. It was found, therefore, that the presence of ethylene glycol enhanced the performance of the battery because of its higher activity and lower charge transfer resistance; and thereby promoted $\mathrm{Al}$ dissolution.

The dual-electrolyte AAFB exhibited linear polarization characteristics. The $\mathrm{OCV}$ of $3 \mathrm{M} \mathrm{KOH}$ ethanol electrolyte, without ethylene glycol, was $1.25 \mathrm{~V}$. When ethylene glycol was added $(5,10,20$, and $30 \%) \mathrm{v} / \mathrm{v}$, the OCVs were $(1.50$, $1.45,1.40$, and $1.35 \mathrm{~V})$, respectively. It was evident, therefore, that by introducing ethylene glycol, the OCV of the battery was enhanced. However, when ethylene glycol content further increased, the OCV of the battery gradually dropped.

Figure 7 displays discharge profiles of the dual-electrolyte Alair battery using an anolyte of ethylene glycol/ethanol solutions $(0,5,10,20$, and $30 \%) \mathrm{v} / \mathrm{v}$ containing $3 \mathrm{M} \mathrm{KOH}$ at a discharge current density of $2.5 \mathrm{~mA} / \mathrm{cm}^{2}$. At discharge current density of $2.5 \mathrm{~mA} / \mathrm{cm}^{2}$, the battery having $5 \% \mathrm{v} / \mathrm{v}$ ethylene glycol achieved the highest specific capacity of $2,100 \mathrm{mAh} / \mathrm{g}_{A l}$ bringing about $70 \%$ utilization efficiency. Moreover, the battery could discharge continuously for more than $24 \mathrm{~h}$. When the ratio of ethylene glycol increased, specific capacity of the battery decreased slightly $\left(2053,1980\right.$, and $\left.1965 \mathrm{mAh} / \mathrm{g}_{A l}\right)$ at the condition of $(10,20$, and $30 \%$ ), respectively. Simultaneously, when the ethylene glycol ratio increased, the average discharge voltage decreased along with $\mathrm{Al}$ utilization percentage. This proved that the AAFB could exhibit a significant higher coulombic efficiency using the electrolyte $3 \mathrm{M}$ $\mathrm{KOH}$ ethanol containing $5 \% \mathrm{v} / \mathrm{v}$ ethylene glycol.

Table 2 presents a comparison of the dual-electrolyte AAFB proposed in this work with other AABs previously reported. Results can vary depending on different parameters, such as cell configuration, ORR catalyst, electrolyte and conditions of the experiment. The dual-electrolyte AAFB exhibited higher specific discharge capacity. Though the dual-electrolyte AAFB using a methanol anolyte showed the highest discharge capacity (Teabnamang et al., 2020), methanol is flammable and volatile. Thus, using the methanol anolyte in an AAFB can pose a safety risk in battery operation. Moreover, methanol has adverse health effects on humans. In contrast, ethylene glycol/ethanol anolyte offers greater safety and is more environmentally friendly, less toxic with trade-off electrochemical performance and discharge capacity. The dual-electrolyte AAFB having the ethylene glycol/ethanol anolyte demonstrated a significantly high discharge capacity. Nonetheless, power density of the dualelectrolyte AAFB must be further improved. Power density depends on numerous factors i.e., ORR catalyst, catholyte, and the structure of a gas diffusion layer. More sophisticated ORR catalysts and different air cathode structure can be applied to improve power density.

TABLE 2 | Comparison of the dual AAFB proposed in this work with other AABs previously reported.

\begin{tabular}{|c|c|c|c|c|}
\hline Configuration & Electrolyte and air cathode & $\begin{array}{c}\text { Maximum } \\
\text { power density } \\
\left(\mathrm{mW} / \mathrm{cm}^{2}\right)\end{array}$ & $\begin{array}{l}\text { Discharge } \\
\text { capacity } \\
\left(\mathrm{mAh} / \mathrm{g}_{A l}\right)\end{array}$ & References \\
\hline Dual electrolyte AAFB & Methanol with $3 \mathrm{M} \mathrm{KOH}, \mathrm{MnO}_{2} / \mathrm{C}$ catalyst & 7.5 & 2,328 & $\begin{array}{l}\text { Teabnamang et al., } \\
2020\end{array}$ \\
\hline Single electrolyte $A A B$ & $4 \mathrm{M} \mathrm{NaOH}$ aqueous solution, $\mathrm{CoO}$ catalyst & 48 & 770.34 & Park et al., 2017 \\
\hline Single electrolyte $A A B$ & $5 \mathrm{M} \mathrm{NaOH}$ aqueous solution with $25 \mathrm{mM}$ thiourea & N/A & 1,282 & Moghadam et al., 2017 \\
\hline Paper-based solid electrolyte AAB & $\begin{array}{l}\text { Gel polymer electrolyte containing } \mathrm{NaOH}, \mathrm{Ag} / \mathrm{C} \\
\text { catalyst }\end{array}$ & 3.8 & 900.8 & Wang et al., 2019 \\
\hline Solid electrolyte AAB & Gel polymer electrolyte $(2 \mathrm{M} \mathrm{KOH}), \mathrm{Pt} / \mathrm{C}$ catalyst & $\mathrm{N} / \mathrm{A}$ & 239 & Yu et al., 2018 \\
\hline
\end{tabular}




\section{CONCLUSION}

In this work, self-corrosion of an $\mathrm{Al}$ electrode in an alkaline dual-electrolyte AAFB was investigated. It is evident that 3 $\mathrm{M} \mathrm{KOH}$ ethanol solution, without ethylene glycol, exhibited excellent corrosion inhibition. However, sluggish Al dissolution kinetics resulted in lower battery performance. Further, the introduction of ethylene glycol to the $3 \mathrm{M} \mathrm{KOH}$ ethanol solution led to enhanced $\mathrm{Al}$ dissolution kinetics. Moreover, both Tafel polarization and EIS confirmed that $3 \mathrm{M} \mathrm{KOH}$ ethanol solution, having $5 \% \mathrm{v} / \mathrm{v}$ ethylene glycol, showed the smallest polarization resistance and the smallest charge transfer resistance. Overall, results demonstrated that the dual-electrolyte AAFB proved to be an effective approach to control anodic corrosion and passivation. It is noted that the dual-electrolyte AAFB performed sufficiently well and provided excellent discharge capacity.

\section{DATA AVAILABILITY STATEMENT}

All datasets generated for this study are included in the article/supplementary material.

\section{REFERENCES}

Abbasi, A., Hosseini, S., Somwangthanaroj, A., Mohamad, A. A., and Kheawhom, S. (2019). Poly(2,6-Dimethyl-1,4-Phenylene Oxide)-based hydroxide exchange separator membranes for zinc-air battery. Int. J. Mol. Sci. 20:3678. doi: 10.3390/ ijms 20153678

Abdel-Gaber, A. M., Khamis, E., Abo-Eldahab, H., and Adeel, S. (2008). Inhibition of aluminium corrosion in alkaline solutions using natural compound. Mater. Chem. Phys. 109, 297-305. doi: 10.1016/j.matchemphys.2007.11.038

Abdel-Gaber, A. M., Khamis, E., Abo-Eldahab, H., and Adeel, S. (2010). Novel package for inhibition of aluminium corrosion in alkaline solutions. Mater. Chem. Phys. 124, 773-779. doi: 10.1016/j.matchemphys.2010.07.059

Abedin, S. Z. E., and Endres, F. (2004). Electrochemical behaviour of Al, Al-In and Al-Ga-in alloys in chloride solutions containing zinc ions. J. Appl. Electrochem. 34, 1071-1080. doi: 10.1023/b:jach.0000042672.23588.df

Chen, L. D., Nørskov, J. K., and Luntz, A. C. (2015). Al-air batteries: fundamental thermodynamic limitations from first-principles theory. J. Phys. Chem. Lett. 6, 175-179. doi: 10.1021/jz502422v

Dilimon, V. S., Hwang, C., Cho, Y.-G., Yang, J., Lim, H.-D., Kang, K., et al. (2017). Superoxide stability for reversible Na-O2 electrochemistry. Sci. Rep. 7:17635.

Gelman, D., Shvartsev, B., and Ein-Eli, Y. (2014). Aluminum-air battery based on an ionic liquid electrolyte. J. Mater. Chem. A 2, 20237-20242. doi: 10.1039/ c4ta04721d

Hong, Q., and Lu, H. (2017). In-situ electrodeposition of highly active silver catalyst on carbon fiber papers as binder free cathodes for aluminum-air battery. Sci. Rep. 7:3378.

Hopkins, B. J., Shao-Horn, Y., and Hart, D. P. (2018). Suppressing corrosion in primary aluminum-air batteries via oil displacement. Science 362:658. doi: 10.1126/science.aat9149

Hosseini, S., Abbasi, A., Uginet, L.-O., Haustraete, N., Praserthdam, S., Yonezawa, T., et al. (2019). The influence of dimethyl sulfoxide as electrolyte additive on anodic dissolution of alkaline zinc-air flow battery. Sci. Rep. 9:14958.

Hosseini, S., Han, S. J., Arponwichanop, A., Yonezawa, T., and Kheawhom, S. (2018a). Ethanol as an electrolyte additive for alkaline zinc-air flow batteries. Sci. Rep. 8:11273.

Hosseini, S., Lao-Atiman, W., Han, S. J., Arpornwichanop, A., Yonezawa, T., and Kheawhom, S. (2018b). Discharge performance of zinc-air flow batteries under the effects of sodium dodecyl sulfate and pluronic F-127. Sci. Rep. 8:14909.

Koroleva, E. V., Thompson, G. E., Hollrigl, G., and Bloeck, M. (1999). Surface morphological changes of aluminium alloys in alkaline solution:: effect of

\section{AUTHOR CONTRIBUTIONS}

SK conceived the research project and wrote the first draft. TP and WK conducted the experiments. TP analyzed the data with consultation from SK. SK, RP, AM, MN, and TY contributed to the subsequent drafts. All authors reviewed the manuscript.

\section{FUNDING}

This research was funded by the Thailand Research Fund (RSA6180008) and Rachadapisek Sompote Fund of Chulalongkorn University.

\section{ACKNOWLEDGMENTS}

The Energy Storage Cluster of Chulalongkorn University was acknowledged.

second phase material. Corros. Sci. 41, 1475-1495. doi: 10.1016/s0010-938x(98) 00188-7

Lao-Atiman, W., Bumroongsil, K., Arpornwichanop, A., Bumroongsakulsawat, P., Olaru, S., and Kheawhom, S. (2019). Model-based analysis of an integrated zinc-air flow battery/zinc electrolyzer system. Front. Energy Res. 7:15.

Li, C.-S., Sun, Y., Gebert, F., and Chou, S.-L. (2017). Current progress on rechargeable magnesium-air battery. Adv. Energy Mater. 7:1700869. doi: 10. 1002/aenm.201700869

Li, Y., Li, Q., Wang, H., Zhang, L., Wilkinson, D. P., and Zhang, J. (2019). Recent progresses in oxygen reduction reaction electrocatalysts for electrochemical energy applications. Electrochem. Energy Rev. 2, 518-538. doi: 10.1007/s41918019-00052-4

Li, Y., and Lu, J. (2017). Metal-air batteries: will they be the future electrochemical energy storage device of choice? ACS Energy Lett. 2, 1370-1377. doi: 10.1021/ acsenergylett.7b00119

Liu, J., Wang, D., Zhang, D., Gao, L., and Lin, T. (2016). Synergistic effects of carboxymethyl cellulose and $\mathrm{ZnO}$ as alkaline electrolyte additives for aluminium anodes with a view towards Al-air batteries. J. Power Sour. 335, 1-11. doi: 10.1016/j.jpowsour.2016.09.060

Liu, Y., Sun, Q., Li, W., Adair, K. R., Li, J., and Sun, X. (2017). A comprehensive review on recent progress in aluminum-air batteries. Green Energy Environ. 2, 246-277. doi: 10.1016/j.gee.2017.06.006

Moghadam, Z., Shabani-Nooshabadi, M., and Behpour, M. (2017). Electrochemical performance of aluminium alloy in strong alkaline media by urea and thiourea as inhibitor for aluminium-air batteries. J. Mol. Liquid. 242, 971-978. doi: 10.1016/j.molliq.2017.07.119

Mohamad, A. A. (2008). Electrochemical properties of aluminum anodes in gel electrolyte-based aluminum-air batteries. Corros. Sci. 50, 3475-3479. doi: 10. 1016/j.corsci.2008.09.001

Mori, R. (2014). A novel aluminium-Air rechargeable battery with $\mathrm{Al} 2 \mathrm{O} 3$ as the buffer to suppress byproduct accumulation directly onto an aluminium anode and air cathode. RSC Adv. 4, 30346-30351. doi: 10.1039/c4ra02165g

Mori, R. (2015). Addition of ceramic barriers to aluminum-air batteries to suppress by-product formation on electrodes. J. Electrochem. Soc. 162, A288-A294.

Mori, R. (2017). Rechargeable aluminum-air battery using various air-cathode materials and suppression of byproducts formation on both anode and air cathode. ECS Transact. 80, 377-393. doi: 10.1149/08010.0377ecst

Mori, R. (2019). All solid state rechargeable aluminum-air battery with deep eutectic solvent based electrolyte and suppression of byproducts formation. RSC Adv. 9, 22220-22226. doi: 10.1039/c9ra04567h 
Nomura, A., Ito, K., and Kubo, Y. (2017). CNT sheet air electrode for the development of ultra-high cell capacity in lithium-air batteries. Sci. Rep. 7:45596.

Park, I.-J., Choi, S.-R., and Kim, J.-G. (2017). Aluminum anode for aluminum-air battery - Part II: Influence of In addition on the electrochemical characteristics of Al-Zn alloy in alkaline solution. J. Power Sour. 357, 47-55. doi: 10.1016/j. jpowsour.2017.04.097

Poolnapol, L., Kao-Ian, W., Somwangthanaroj, A., Mahlendorf, F., Nguyen, M. T., Yonezawa, T., et al. (2020). Silver decorated reduced graphene oxide as electrocatalyst for zinc-air batteries. Energies 13:462. doi: 10.3390/en13020462

Pyun, S.-I., and Moon, S.-M. (2000). Corrosion mechanism of pure aluminium in aqueous alkaline solution. J. Solid State Electrochem. 4, 267-272. doi: 10.1007/ s100080050203

Rashvand, A. M., Jafarian, M., Moghanni, B. O. H., Gobal, F., Hosseini, S. M., et al. (2013). Study of the alloying additives and alkaline zincate solution effects on the commercial aluminum as galvanic anode for use in alkaline batteries. Mater. Chem. Phys. 143, 133-142. doi: 10.1016/j.matchemphys.2013.08.035

Ryu, J., Jang, H., Park, J., Yoo, Y., Park, M., and Cho, J. (2018). Seedmediated atomic-scale reconstruction of silver manganate nanoplates for oxygen reduction towards high-energy aluminum-air flow batteries. Nat. Commun. 9:3715.

Shinagawa, T., Garcia-Esparza, A. T., and Takanabe, K. (2015). Insight on Tafel slopes from a microkinetic analysis of aqueous electrocatalysis for energy conversion. Sci. Rep. 5:13801.

Shrestha, N., Raja, K. S., and Utgikar, V. (2019). Mg-RE alloy anode materials for mg-air battery application. J. Electrochem. Soc. 166, A3139-A3153.

Teabnamang, P., Kao-Ian, W., Nguyen, M. T., Yonezawa, T., Cheacharoen, R., and Kheawhom, S. (2020). High-capacity dual-electrolyte aluminum-air battery with circulating methanol anolyte. Energies 13:2275.

Verma, C., Singh, P., Bahadur, I., Ebenso, E. E., and Quraishi, M. A. (2015). Electrochemical, thermodynamic, surface and theoretical investigation of 2aminobenzene-1,3-dicarbonitriles as green corrosion inhibitor for aluminum in 0.5M NaOH. J. Mol. Liquid. 209, 767-778. doi: 10.1016/j.molliq.2015. 06.039

Wang, D., Li, H., Liu, J., Zhang, D., Gao, L., and Tong, L. (2015a). Evaluation of AA5052 alloy anode in alkaline electrolyte with organic rare-earth complex additives for aluminium-air batteries. J. Power Sour. 293, 484-491. doi: 10.1016/ j.jpowsour.2015.05.104

Wang, D., Zhang, D., Lee, K., and Gao, L. (2015b). Performance of AA5052 alloy anode in alkaline ethylene glycol electrolyte with dicarboxylic acids additives for aluminium-air batteries. J. Power Sour. 297, 464-471. doi: 10.1016/j.jpowsour. 2015.08.033
Wang, J. B., Wang, J. M., Shao, H. B., Chang, X. T., Wang, L., Zhang, J. Q., et al. (2009). The corrosion and electrochemical behavior of pure aluminum in additive-containing alkaline methanol-water mixed solutions. Mater. Corros. 60, 269-273. doi: 10.1002/maco.200805074

Wang, J.-B., Wang, J.-M., Shao, H.-B., Zhang, J.-Q., and Cao, C.-N. (2007). The corrosion and electrochemical behaviour of pure aluminium in alkaline methanol solutions. J. Appl. Electrochem. 37, 753-758. doi: 10.1007/s10800007-9310-8

Wang, L., Liu, F., Wang, W., Yang, G., Zheng, D., Wu, Z., et al. (2014). A high-capacity dual-electrolyte aluminum/air electrochemical cell. RSC Adv. 4, 30857-30863. doi: 10.1039/c4ra05222f

Wang, Y., Pan, W., Kwok, H., Lu, X., and Leung, D. Y. C. (2019). Low-cost Al-air batteries with paper-based solid electrolyte. Energy Proc. 158, 522-527. doi: 10.1016/j.egypro.2019.01.146

Weon, J.-I., and Woo, H.-S. (2013). Corrosion mechanism of aluminum alloy by ethylene glycol-based solution. Mater. Corros. 64, 50-59. doi: 10.1002/maco. 201106222

Yoo, K., Banerjee, S., Kim, J., and Dutta, P. (2017). A review of lithium-air battery modeling studies. Energies 10:1748. doi: 10.3390/en10111748

Yu, Y., Chen, M., Wang, S., Hill, C., Joshi, P., Kuruganti, T., et al. (2018). Laser sintering of printed anodes for al-air batteries. J. Electrochem. Soc. 165, A584-A592.

Zaharieva, J., Milanova, M., Mitov, M., Lutov, L., Manev, S., and Todorovsky, D. (2009). Corrosion of aluminium and aluminium alloy in ethylene glycol-water mixtures. J. Alloys Comp. 470, 397-403.

Zhang, G. A., Xu, L. Y., and Cheng, Y. F. (2008). Mechanistic aspects of electrochemical corrosion of aluminum alloy in ethylene glycol-water solution. Electrochim. Acta 53, 8245-8252.

Zuo, Y., Yu, Y., Zuo, C., Ning, C., Liu, H., Gu, Z., et al. (2019). Low-temperature performance of Al-air batteries. Energies 12:612.

Conflict of Interest: The authors declare that the research was conducted in the absence of any commercial or financial relationships that could be construed as a potential conflict of interest.

Copyright $\odot 2020$ Phusittananan, Kao-Ian, Nguyen, Yonezawa, Pornprasertsuk, Mohamad and Kheawhom. This is an open-access article distributed under the terms of the Creative Commons Attribution License (CC BY). The use, distribution or reproduction in other forums is permitted, provided the original author(s) and the copyright owner(s) are credited and that the original publication in this journal is cited, in accordance with accepted academic practice. No use, distribution or reproduction is permitted which does not comply with these terms. 